\title{
REMOTE SENSING STRATEGIES FOR LITHOLOGICAL MAPPING OF PAN AFRICAN ASSEMBLAGES IN ARID ENVIRONMENTS - A CASE STUDY IN ERITREA, NE AFRICA
}

\author{
C.R.Souza Filho ${ }^{1} \&$ S.A.Drury ${ }^{2}$
}

\section{KEY-WORDS: Remote sensing, spectral, Pan African.}

SOUZA FILHO, C.R.; DRURY, S.A. (1997) Remote sensing strategies for lithological mapping of Pan African assemblages in arid environments - a case study in Eritrea, NE Africa Bol.IG-USP. Sér.Cient, 28:1-22.

\section{ABSTRACT}

Over a 30 year period, when major advances were made in understanding the evolution of the Arabian-Nubian Shield, military conflicts prevented the geological mapping and tectonic interpretation of Eritrea, NE Africa. The indication of small occurrences of ultramafic rocks through ancient work in the NW extremity of the country prompted many workers on regional tectonics to propose the line of the Barka river as a Neoproterozoic (Pan African) suture. Several attempts based on remote sensing data have been considered to resolve about the existence of such structure in this region. These previous approaches, based on Landsat TM band ratios, fail comprehensively in Eritrea both to unequivocally map ultramafic occurrences and to serve as a good basis for lithological mapping, producing inconclusive and divergent overall results.

In this paper we attempt to verify and amplify the hypothesis of a suture zone in NW Eritrea, employing a novel remote sensing strategy and detailed field work. Using statistically-selected Landsat TM enhanced false colour composites together with renditions from residual information of favored Principal Components (pseudo-ratios), we demonstrate that many important components of the Pan African Terranes of Eritrea - i.e. ophiolitic assemblages - can be mapped with a high degree of confidence. This remote sensing strategy transcends the problems encountered in previous approaches in Eritrea and can potentially serve as a powerful tool for geological mapping of similar arid terrains elsewhere.

\section{RESUMO}

Durante um periodo de cerca de 30 anos, enquanto grandes avanços eram alcançados no entendimento da evolução do Escudo Arábico-Nubiano, conflitos militares impediram que qualquer tipo de mapeamento geológico e interpretaçāo tectônica fossem realizados na Eritrea, regiâo do NE da Africa. A indicação, a partir de trabalhos da década de 50 , da ocorrência de rochas ultramáficas na extremidade noroeste do pais, levou diversos autores a propor a existência de uma zona de sutura Neoproterozóica (Pan Africana) ao longo do rio Barka. Diversas tentativas no sentido de demonstrar a existência desta zona de sutura na região vêm sendo feitas desde então, todas baseadas exclusivamente em dados de sensoriamento remoto. Entre estes trabalhos prévios, destacam-se aqueles que utilizam-se de variações da técnica de razões de bandas do satélite Landsat TM. Essas técnicas, entretanto, são incapazes de mapear inequivocamente a ocorrência de rochas ultramáficas e de gerar produtos que possam servir como uma boa base para o mapeamento litológico. A comparação entre os resultados obtidos

\footnotetext{
'Instituto de Geociências/UNICAMP, Campinas, SP, Brasil.

'Department of Earth Sciences, The Open University, Milton Keynes, United Kingdom.
} 
nesses trabalhos mostram incertezas e divergências marcantes.

Neste artigo, pretende-se verificar e expandir a hipótese da existência de uma zona de sutura no NW da Eritrea, utilizando uma estratégia de sensoriamento remoto inédita e dados de trabalhos de campo de detalhe. Esta estratégia emprega composiçōes coloridas de bandas do sensor Landsat TM, selecionadas por métodos estatisticos e realçadas espectralmente, em conjunto com composições coloridas geradas a partir da informação residual de Componentes Principais (pseudo-razỏes), para o mapeamento das principais feiçôes dos terrenos Pan Africanos da Eritrea (i.e. sequências ofioliticas). A estratégia proposta transcende os problemas encontrados em outras tentativas de mapeamento destas feiçōes e potencialmente pode ser adotada como uma poderosa ferramenta na caracterizaçăo de áreas geologicamente similares, em regiōes de clima árido.

\section{INTRODUCTION}

The Neoproterozoic, Nubian-Arabian Shield is regarded as having been assembled mainly from oceanic island arcs in the last 200-300 Ma of the Proterozoic (Stoeser \& Camp, 1985; Stern, 1994). Major tectonic boundaries incorporate isolated and variably deformed masses of ultramafic and mafic rocks, which display some if not all of the attributes of ophiolites. Most Pan African researchers consider these ophiolite-decorated boundaries to be the former sites of subduction (Vail, 1985; and references therein). The island arcs, their sedimentary aprons and slivers of oceanic lithosphere accreted by obliqueslip processes to assemble the current shield, probably between $640-550 \mathrm{Ma}$ (Stern, 1994).

In the large Nubian-Arabian Shield remote sensing approaches are essential in interpolation between a few geo-traverses that have been followed. As well as allowing geologists to trace the regional grain, the spectral information in data such as the Landsat Thematic Mapper (TM) and the Japan Earth and Resources Satellite-1 (JERS-1) Optical System (OPS) encourage attempts to discriminate and map a variety of rock types throughout the well-exposed parts of the shield. Foremost among these lithological "targets" are those that allow confident identification of disrupted portions of oceanic lithosphere, i.e. serpentinized peridotitic and dunitic rocks, that may mark sutures.
Northern Eritrea (Fig. 1) has remained undescribed by geologists for about 40 years. Scanty early accounts of the presence of serpentinites near to a major lineament along the lower Barka river (Francaviglia, 1938, 1943; Usoni, 1952; Kazmin, 1973, 1976; Mohr, 1979) prompted notions that the boundary is a terrane-bounding structure: a suture zone (Vail, 1985; Kroner et al., 1987; Berhe, 1990). The existence and location of such suture zone is therefore conjectural and has not been demonstrated.

A number of researchers have used Landsat TM data for reconnaissance mapping of the Pan African (e.g. Sultan et al., 1986, 1987, 1988, 1992, 1993; Berhe \& Rothery, 1986; Miller \& Dixon, 1992; Drury \& Berhe, 1993). Two main enhancement approaches have been adopted for geological applications. One uses general purpose renditions of broad spectral and spatial variations (e.g. Drury \& Berhe, 1993) the other focuses image products on critical lithological associations, such as serpentinites and granites (e.g. Sultan et al., 1986). Using Landsat TM data only, Sultan et al. (1993) assigned a series of N-S ridges close to the Barka lineament in Eritrea to the presence of serpentinites. Also on the basis of remotely sensed data alone, Drury \& Berhe (1993) inferred the presence in Eritrea of serpentinite masses in several large elliptical bodies and linear belts 


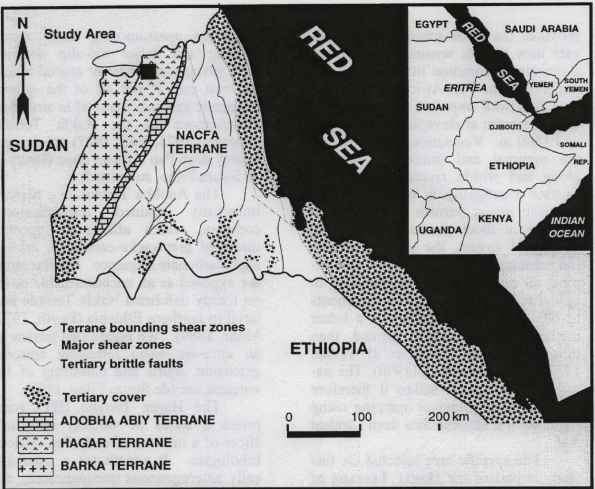

Figure 1 - Generalized sketch map showing the preliminary tectonic subdivision of Northern Eritrea based on interpretation of field-checked remotely sensed data (De Souza Filho, 1995). The patterned square indicates the study area.

east of the Barka river, however in different locations from those marked by Sultan et al. (1993).

In view of the inconclusive and divergent results obtained by Sultan et al. (1986) and Drury \& Berhe (1993) on the basis of remote sensing data only, the need to elucidate the actual existence and distribution of serpentinite bodies and their indication of a suture zone in northern Eritrea is evident. Here we attempt to verify and amplify this important hypothesis, using both detailed field and image analysis of Landsat data. This paper has a threefold approach: (1) firstly, the techniques of Sultan et al. (1986) and Drury \& Berhe
(1993) to map Pan-African associations in NE Africa are re-evaluated, using laboratory spectra and the Eritrean context as a control; (2) secondly, a remote sensing strategy for geologic mapping of these terrains that transcends the problems encountered in these two previous approaches in Eritrea and in similar terrains elsewhere in NE Africa is proposed; and ( 3 ) finally, the regional geological implications of the results are addressed in the context of the Nubian-Arabian Shield.

\section{STUDY AREA}

The geology of northern Eritrea 
provides the ideal scenario to investigate how remote sensing methods can discriminate common lithological components of the Pan African. The study area is a well exposed, rugged mountainous terrain at elevation between 250 and $1600 \mathrm{~m}$. Vegetation and cover soil are minimal and limited to terraces along and within rivers and streams. Surface weathering is not severe and iron-rich desert varnish is weakly developed in most places. As regards geological targets, the region includes the association of serpentinites with almost all major rock types identified in ophiolites and island arc environments in NE Africa and therefore is a better methodological proving ground than those chosen by Sultan et al. (1986, 1987) and Rivard et al. (1990). The nature of this terrain makes it therefore suitable for lithological mapping using multispectral satellite data from Landsat TM

The specific area selected for this study is part of the Hagar Terrane of northwestern Eritrea (Fig. 1), which lies east of a major regional lineament (the Barka lineament) that includes serpentinites inferred by Sultan et al. (1993) and Drury \& Berhe (1993).

\section{Geologic Setting}

De Souza Filho (1995) established a fourfold tectonic framework for the Precambrian of northern Eritrea (Fig. 1). The eastermost Nakfa Terrane is dominated by a twofold supracrustal division beginning with primitive, submarine arc volcanics with minor exhalative chemogenic sediments, and a higher sequence of more evolved calcalkaline volcanics erupted subaerialy, on top of which a sequence of volcaniclastic and carbonate basin-fill sediments evolved. This association is underpinned by pre- to early-synkinematic diorite to granodiorite bodies. Deformation is variable within and between numerous anastomosing shear zones. Folding and major dip-slip shearing have juxtaposed different crustal levels. At least part if not all of the quartzfeldspatic gneisses exposed in structural culminations in the Nakfa Terrane (Kazmin, 1973; Vail, 1987) are demonstrably deep Pan African crust (Drury \& de Souza Filho, submitted).

The Adobha Terrane is a narrow, immensily strained, transpressional complex, which affects an upward, threefold graywacke-carbonate, arkose, algal carbonate sequence. Similar strata are exposed as an unconformable cover on lightly deformed Nakfa Terrane material in northern Ethiopia (Beyth, 1972; Mohr, 1989). We regard that terrane as an intra-arc basin reflecting episodic extension, uplift and unroofing of the volcanic arc (de Souza Filho, 1995).

The Hagar Terrane (HT) comprises a series of variably deformed slices of a mixture of early Pan African lithologies. It constitutes a lithologically heterogeneous transpressional duplex, thrust eastwards over the Adobha Abiy Terrane to overstep onto the Nakfa Terrane in NE Eritrea (Fig. 1).

Westernmost Eritrea, abutting the Hagar and Adobha Abiy Terranes along the Barka river, comprises mid- to upper amphibolite-facies gneisses, metabasaltic amphibolites and a range of mature pelitic and carbonate sediments. This Barka Terrane is an exotic microcontinental mass juxtaposed against the arc assembly of the Eritrean Pan African by large strike-slip movement along the Barka lineament.

The only other recent study in this part of the Nubian Shield is that of Kroner et al. (1991) in the Tokar area of Sudan. They decribed a simple bimodal assembly of minor basaltic and dominant silicic metavolcanics, dated at 840 $\mathrm{Ma}$, which is intruded by pre- to early synkinematic granitoids (827 Ma). Geochemical aspects of the silicic vol- 
canics suggest an affinity with the $\mathrm{Al}$ lith area of the Arabian Shield. They ascribed this assemblage to what they termed the "Tokar Terrane".

\section{The Western Hagar Terrane Trav- erse}

Figure 2 shows a comprehensive division of all lithologies that are represented in our traverses in a $30 \times 30 \mathrm{~km}$ area in the western Hagar Terrane - this forms the focus of this paper. Important tectonic descontinuites and the major lithological components making up each of the tectocnic blocks are addressed. Discussion on the nature of these tectonic boundaries and structural style of the internal masses are beyond the scope of this paper and are discussed elsewhere - de Souza Filho and Drury, in press (a).

All lithologies in the western $\mathrm{Ha}$ gar Terrane are at greenschist metamorphic grade. In tectonic contact with high-grade rocks of the Barka Terrane the westernmost Hagar rocks comprise an intensely folded and imbricated complex of chloritic phyllites, dark impure carbonates, metabasalts and metagabbros (see map of Fig. 2), the supracrustal rocks forming numerous ridges and valleys. This part is characterized by a multitude of lineaments, extending several kilometres long. Within $10 \mathrm{~km}$ of the western limit, it is replaced by a chaotic zone up to $15 \mathrm{~km}$ across (Fig. 2). This is a jumble of isolated masses of different rock types from centimetres to $>1 \mathrm{~km}$ across, set in a poorly sorted matrix of sericitic, epidotic, chloritic and serpentinitic debris. Clasts include basalts, serpentinites, gabbros, pure and imature carbonates, and Fe-Mn cherts. This is a major olistostromic mélange, which although variably deformed preserves clear evidence of sedimentary disaggregation to be ascribed to repeated submarine slumping as well as tectonic disruption. A large discontinu- ous ridge of dark impure carbonate and a $5 \times 0.5 \mathrm{~km}$ lens of lizardite-antigorite serpentinite are associated with its western flank (Fig. 2). For reference purposes we term the westernmost Hagar assemblages the Tectonic Block 1 (TB1).

A sharp tectonic contact separates the olistostrome from a different lithological assemblage to the east. This, Tectonic Block 2 (TB2), comprises a sequence of intact and lightly deformed massive and pillowed basaltic andesite and andesite lavas with various subaqueous pyroclastics, turbitic sediments, and Fe-Mn cherts separated by occasional thin olistostromes with polymict clasts up to a metre across (Fig. 2). Within the supracrustal rocks are minor pyroxenite and gabbro cumulates. TB2 is intruded by several diorite, tonalite and granodiorite pre- and early synkinematic bodies, some of which are associated with more evolved dacitic volcanic rocks at high elevation.

\section{EXPERIMENTAL METHODS}

\section{Background}

The rationale behind lithological mapping of a specific rock (e.g., serpentinites) using multispectral satellite data cannot be addressed solely on the basis of its own spectral characters, but should include a broad knowledge of the spectral signatures of the whole lithological range of a terrain, including those affected by weathering and desert varnish. This is because there are few rock-forming and weathering minerals whose absorptions are strong enough to be detected by broad-band satellite data and thereby contribute to separable spectral variations. This implies that a suite of several rocks, each containing minerals with similar spectral signatures, may only be mapped as a single lithological unit using satellite data.

Serpentinites are produced by re- 


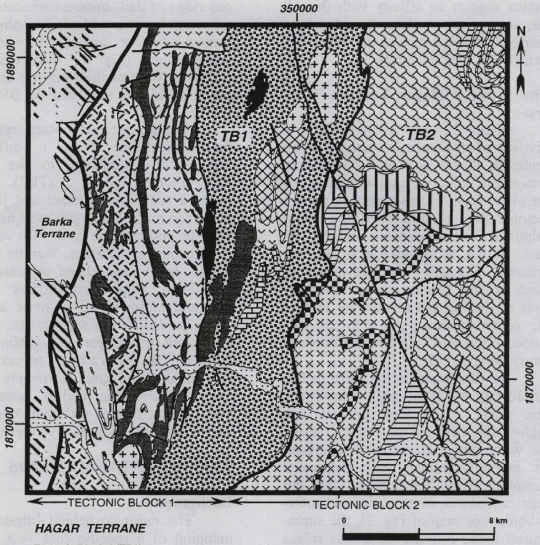

Tectonic Block 1 (TB1)

Serpentinite

Marble 1 (impure, dark)

F. Gabbro 2 (dominant) and metabasalt

Exotic amphibolite and gneiss
69 Olistostromic mélange

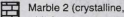
white)

Chlorite-schists

(Barka Terrane provenance)
Massive and pillow basalt

Q Gabbro 1 (epidote-rich)

+ Granodiorite and diorite

Recent sediments

Tectonic Block 2 (TB2)

57 Andesites and dacites

(dominant) plus granodiorite. dionte, quartz-diorite and rare gaboro, olistostrome.

Ex Grancdiorite and diorite plutons (dominant); minor gabbro

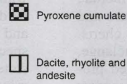

Pyro-and volcanoclastics
(dominant); minor
andesite and dacite

Figure 2 - Lithological map of the study area. 
placement of olivine and pyroxene by hydrous minerals of the serpentine group. Mineralogical and spectral properties of these rocks are well known (see Hunt \& Evarts, 1981). They are distinguishable (Hunt \& Evarts, 1981; Sultan et al., 1986) because of (1) their high content of ironpoor, OH-bearing phases (antigorite, lizardite, chrysotile and talc) that display intense sharp double or multiple absorption bands near 1.4 and $2.3 \mu \mathrm{m}$, the latter and most important being attributed to the combination of the $\mathrm{OH}$ stretching fundamental with the $\mathrm{MgOH}$ bending mode (Hunt \& Evarts, 1981); and (2) their high content of magnetite, an opaque mineral which exhibits very low flat reflectance spectra (Hunt \& Evarts, 1981).

Sultan et al. $(1986 ; 1987)$ showed that serpentinites differ spectrally from most lithologies in the Central Eastern Desert of Egypt by comparing relative reflectance extracted from ratios of TM data of well-known outcrops. They found that (1) increasing amounts of magnetite decreases the ratio of TM band $5(1.55-1.75 \mu \mathrm{m})$ to TM band 1 $(0.45-0.52 \mu \mathrm{m})$; (2) increasing amounts of minerals of the serpentines and carbonates, with pronounced absorptions in the $2.3 \mu \mathrm{m}$ region of the electromagnetic spectrum (covered by the TM band 7 bandwidth - 2.08-2.35 $\mu \mathrm{m}$ ) increases the ratio of band 5 to band 7 ; and (3) increasing amounts of Fe-bearing alluminosilicates (e.g., hornblende) increases the product of the ratio TM5/TM4 and TM3/TM4 (Sultan et al., 1988). However, they largely focused their work on distinguishing serpentinites from the surrounding 'granitegneissic' sequences, whose field characteristics, compositional and spectral attributes differ markedly from that of serpentinites. Sultan et al. (1986) encountered difficulties in separating serpentinites from dominantly chloritic greenschist facies metavolcanics, using their approach. This is precisely the problem in Eritrea.

The approach of Drury \& Berhe (1993) for mapping serpentinites is similar to that of Sultan et al. (1986; 1987), but differs regarding the use of magnetite as a major discriminating factor. Drury \& Berhe (1993) argued that variable oxidation of exsolved magnetite to hematite may contribute more significantly to the spectral signature of serpentinite surfaces exposed in semi-arid environments. They observed that (1) the increase of ferric oxide/hydroxide content increases the ratio between TM3 and TM1 (the higher the ratio the 'redder' the surface); (2) increasing amounts of ferric mineral content, particularly that of hematite, increases the ratio between TM5 and TM4; and (3) increasing content of clays, chlorites and serpentine, decreases the ratio between TM7 and TM5, without however permitting discrimination between them, due to the breadth of TM7.

Both approaches, though robust in theory, show several practical limitations. They lack spectral analysis of the rocks found in the field. The effect and extent of oxidation of magnetite to hematite in controlling the overall albedo of serpentinite surfaces was not resolved. Sultan et al. (1986) did not examine critically the occurrence of serpentinites in the bulk of Pan African terrains. Greenschist facies basic to intermediate meta-volcanics and metaplutonics also have a combination of mafic hydroxyl-bearing silicates and magnetite, that make them spectrally similar to serpentinites. The prominence of these rocks elsewhere in the Nubian-Arabian Shield received little consideration. Their assumption that serpentinites can be distinguished from marbles on the basis of the lack of opaque phases in the latter disregards 
the existence of large tracks of impure sea-floor carbonates. These are common in NE Africa in close association with serpentinites or as isolated entities in sheared belts (Shackleton, 1994). Such marbles are dark coloured due to the presence of large amounts of carbonaceous material, which show low, flat spectra throughout the whole 0.4-2.5 $\mu \mathrm{m}$ range (Hunt \& Salisbury, 1970), and therefore, have a spectral effect similar to that of magnetite.

\section{Modelling of Lab Spectra Ratios}

We determined laboratory spectra for 60 oriented samples from which 19 non-redundant spectral sets were selected for examination here. Between four and eight reflectance spectra were produced for each natural rock surface, for fresh broken surfaces and for varnish or sediment coatings (broken surfaces) and with varnished-weathered veneers (upper free surfaces). Reflectance spectra in the $400 \mathrm{~nm}$ to $2400 \mathrm{~nm}$ region were measured using a GER IRIS spectroradiometer with a pressed $\mathrm{BaSO}_{4}$ reference panel (see Milton \& Rollin, 1987). No significant SWIR spectral differences were found between broken and upper free surfaces for all lithologies but serpentinites, and therefore only lab spectra of weathered surfaces of the latter are used here. However, it is worth mentioning the fact that most of the varnished-weathered surfaces show similar, more intense absorptions in the visible part of the spectrum when compared to the broken surfaces. These features reflect an increase in iron staining and have similar shape and depth for all mafic and intermediate lithologies, suggesting that they suffered an overall homogeneous effect of surficial alteration processes.

The average of available reflectance spectra for each of the selected rock surfaces was convolved across the TM bands using filter functions calcu- lated from TM sensor response curves (see Milton \& Rolim, 1987). Figure 3 shows these convolved spectra expressed as the TM band ratios proposed by Sultan et al. (1987) and Drury \& Berhe (1993). Using TM5/TM7 ratios, serpentinite, despite the nature of its surface (whether fresh (F), weathered (W) or composed of coarse pure serpentine $(\mathrm{P})$ ), is readily distinguishable from most lithologies but particularly from sheared dacites and silicic volcaniclastics (usually containing abundant sericite and chlorite and low opaques), and crystalline opaque-free carbonates. Perhaps distinct but close to the spectral response of serpentinites are the pyroxene cumulates (serpentinized pyroxenes immersed in a voluminous epidotic-chloritic matrix), impure dark marbles (where carbonates are mixed with fine carbonaceous material), and some of the gabbros and basalts (both essentially composed by variable amounts of amphibole, plagioclase, epidote, chlorite, quartz and high content of opaques). This ratio first indicates that the original content of magnetite in the serpentinite did not quench its SWIR absorptions. Conversely, the presence of carbonaceous material in the impure marbles reduced to some degree the SWIR absorptions of carbonates, which are spectrally equivalent to those of serpentinite. Andesites, diorites, granodiorites, and some basalts show similar low ratios and could be mapped as a single assemblage in TM5/TM7 images.

In TM5/TM1 ratios, weathered and fresh serpentinites show large differences in albedo from pure serpentine, because of their higher content in magnetite. Crystalline marbles and granodiorites, with low abundance of opaque phases, show the highest ratios. Crystalline marbles, with similar TM5/TM7 ratios to serpentinites are readily distinguishable in TM5/TM1 ratios, as also 
verified by Sultan et al. (1986) in Egypt, and confirm the fact that magnetite is an important component controlling surface albedo. Impure marbles, however, displays ratios close to those of serpentinites due its content of carbonaceous matter. Gabbros and basalts exhibit marked ratio variations which reflect their variable content of magnetite and other opaque phases; their higher ratio values and those of pyroxenites, however, do provide discrimination from serpentinites.

In TM5/TM4 x TM3/TM4 ratios, serpentinite and impure marbles show similar values. The only outstanding contrast in this combination is that between amphibolites and pure serpentine. Most of the remaining rocks show similar average values. The TM5/TM4 ratios, at least for the greenschist rocks of Eritrea, very much resemble those obtained by multiplying TM5/TM4 $\mathrm{x}$ TM3/TM4, suggesting that the operation introduced by Sultan et al. (1986) is unnecessary. Using TM3/TM1, serpentinites and crystalline marbles show an inverse relation, but the same does not apply for impure marbles whose ratios are close to those of serpentinites. Serpentine, andesites, dacites, diorites, rhyolites, granodiorites, show surfaces containing similar amounts of iron but should be distinct from the iron-richer pyroxene cumulates, amphibolites and some basalts and gabbros. The TM7/TM5 ratios have the same discrimination properties of TM5/TM7, though the ratio values are inverted.

\section{Colour Model for Image Display}

On the basis of the relative spectral responses of the TM ratios shown in Figure 3 , one can simulate a red-greenblue (RGB) colour model to predict to which probable hues some of these lithologies should be associated in the imagery. In Sultan et al.'s (1987) false colour composite (FCC) image
$($ TM5/TM4 $\times$ TM3/TM4 = blue, TM5/TM1 = green, $\mathrm{TM} 5 / \mathrm{TM} 7=$ red), some specific rocks can be mapped. Serpentinites, having abundant hydroxyl minerals (high TM5/TM7), opaque phases (low TM5/TM1), and low content of Fe-bearing alluminosilicates (low TM5/TM4 x TM3/TM4), should appear as red (high TM5/TM7). They can be distinguished from opaque-free crystalline marbles, as the latter show higher values in TM5/TM1. However, the same serpentinites show little contrast with the impure marbles in all ratios, and both are expected to appear in similar red hues. The same applies to some sheared volcaniclastics. Some gabbros, with spectral characteristics close to those of serpentinites may also show as variations of red colours, but these variations should comprise deeper red tones because of their content in Febearing aluminosilicates. Granitic rocks with low opaques (high TM5/TM1), hydroxyl-bearing phases (low TM5/TM7) and Fe-bearing aluminosilicates (low TM5/TM4 x TM3/TM4) should show as green hues (Sultan et al., 1987). Though this is successful for granitic-gneissic rocks in the Central Eastern Desert of Egypt, it does not distinguish granodiorites in Eritrea, which instead show intermediate to high ratios on TM5/TM7 and TM5/TM4 x TM3/TM4 and should show as a mixture of hues between cyan and magenta. Most of the mafic rocks (amphibolites, basalts and gabbros), generally rich in Fe-bearing alluminosilicates and spectrally opaque phases should show as variation of blue hues (TM5/TM4 x TM3/TM4 high). Intermediary rocks (andesites, diorites) may be confused with the more mafic equivalents.

In Drury \& Berhe's (1993) FCC image $(\mathrm{TM} 7 / \mathrm{TM} 5=$ blue, $\mathrm{TM} 3 / \mathrm{TM} 1=$ green, TM5/TM4 = red), serpentinites, impure marbles and some sheared vol- 
caniclastics should show as similar variations of green hues. Diorites, andesites and some of the gabbros and basalts should be displayed as light orange to magenta tones because of their higher values in TM5/TM4 and homogeneous intermediate and high values in ratios TM3/1 and TM7/TM5, respectively. Granodiorites may show some more distinct hues towards light magenta, but confusion between them and other intermediate to acid metavolcanics and metaplutonics is expected.

Having considered a colour model to predict the colours in which some of the rocks should appear in previously used ratio combinations, in the next section we evaluate this model in helping to identify and discriminate these lithologies in actual TM images. This is followed by showing the possible improvements using our optimised image processing strategy.

\section{REMOTE SENSING DATA AND IMAGE PROCESSING METHODS}

\section{Landsat TM Data - Ratio Techniques}

Figure 4 is a FCC of ratios equivalent to those proposed by Sultan et al. (1987). Using Figure 2 as a reference, the Hagar Tectonic Block 1 (TB1) is dominated by red and blue hues, and the Tectonic Block 2 (TB2) comprises complex variations in light green and blue, pale magenta and few sparse traces of red components. This spectral contrast between TB1 and TB2 is attributed to major differences in composition between these blocks. The overall spectral signature of TB1 indicates it to be richer in mafic components (blue colour) when compared to TB2.

Comparing Figure 4 with Figure 2 in the light of the colour model previously discussed for this rendition gives the following in TB1:

(i) Serpentinites and impure mar- bles show as similar red hues. They could be misinterpreted as part of a same unit. This apparently was the fact that led Sultan et al. (1993) to incorrectly identify the impure marbles with serpentinites;

(ii) Chlorite-schists (volcaniclastics) that in places dominate the matrix of the mélange unit also show similar red colours and so pose a further problem for detection of serpentinites;

(iii) Crystalline marbles show a mixture of pale red with patches of more pure red, which may indicate that they are in fact only locally free of impurities;

(iv) The large elliptical gabbroic bodies in the east of TB1, although showing as reddish, are visually distinct from the above lithologies (paler reddish brown).

(v) The western gabbros, amphibolites, basalts and derived sediments and southern tracts of the mélanges, are all mapped as similar shades of blue;

(vi) Granodiorites and diorites in TB1 have a different texture and spectral signature from all mafic rock types. Their lighter greenish colours indicate acid to intermediate composition and low content of opaques.

In TB2, although the rocks are coherently distributed along strike and in folded structures, there are few lithologies than can be confidently discriminated in Figure 4 on the basis of reasonable and understandable spectral variations. It is observed that:

(i) Volcaniclastics associated with acid metavolcanics are displayed as red. The spectral signature of these rocks, close to that of serpentinites in these images, are of special interest. East of the studied area, there is a immense increase in the volume of these rocks and associated dacites and ignimbrites. There, these volcaniclastics appear as long NNE-SSW belts which are shown as conspicuous 'red' linear features in 
the mosaic produced by Sultan et al. (1993); these features were also erroneously assigned as possible serpentinites in their map;

(ii) Dacites and rhyolites show as pale white to light pink colours but their discrimination from the surrounding rocks does require careful examination,

(iii) Andesites, basaltic andesites, diorites, granodiorites, gabbros and pyroxene cumulates are all mapped as a spectrally complex assemblage displaying subtle variation in both light green and pale magenta colours, making their characterisation extremely difficult on Figure 4. Surfaces that exhibit more homogenous textural and spectral information may be associated with undifferentiated but dominantly plutonic rocks. However, the same rocks are found as sheets and layers within the 'layered' metavolcanics and metavolcaniclastics.

Figure 5 is a FCC equivalent to that proposed by Drury \& Berhe (1993). Still using Figure 2 as a reference, it is seen that in TB1, serpentinites, impure marbles and tracts of the mélange matrix (volcaniclastics) are all mapped as similar green tonal variations. The eastern elliptical gabbroic bodies are also displayed as green colours, closer to serpentinites than those displayed in Sultan's FCC. This ratio combination also seems to be aesthetically worse than the previous by displaying vegetation along rivers in green. The western gabbros, amphibolites and basalts appear in pink to light purple hues. The majority of what is defined here as the TB1 was interpreted as a volcano-sedimentary sequence by Drury \& Berhe (1993).

The FCC of Figure 5, like Figure 4 , does not clearly discriminate the lithological components of TB2. The lack of large spectral contrast and therefore, the 'homogeneous' appearance of this domain on images, prompted Drury
\& Berhe (1993) to erroneously suggest that it and similar surfaces in western Eritrea could be large serpentinite bodies. The fact that these rocks are mapped as similar assemblages in TM imagery may be explained by a combination of two factors: (1) their similar content in minerals with distinct (epidote, chlorite) or no (magnetite) absorptions and, (2) their similar surficial alteration by weathering and desert varnish. The latter is supported by the close shape and depth of most absorptions recorded for TB2 rock types in lab measurements (pyroxene cumulates, gabbros, andesites, diorites and granodiorites).

The procedures introduced by Sultan et al. $(1986 ; 1987)$ for regional mapping of serpentinites in Pan African terrains showed inferior results in Eritrea when compared to those obtained in the Central Eastern Desert of Egypt. Associations similar to that in TB1, comprising serpentinite lenses, other oceanic floor assemblages and flattened and stretched tracts of dark impure marbles, are common in other Pan African terrains elsewhere in the shield (e.g., Shackleton, 1994). This suggests caution when analysing the regional mosaics and maps produced by Sultan et al. $(1986 ; 1987 ; 1998 ; 1993)$. Many rocks identified there as serpentinites may in fact be impure marbles, volcaniclastics or even gabbros. Therefore, postulated suture zones which might be implied by these 'serpentinite' occurrences may be illusory. Such images also contain little or indeterminate information relating to other mineralogical variations, and are therefore of limited use. The same applies to images processed in the manner of Drury \& Berhe (1993). We have also experimented with decorrelation stretched TM 7,5,4 (RGB) combination, which were successfully used to map the Cretaceous Oman ophiolite (Rothery, 1987; 

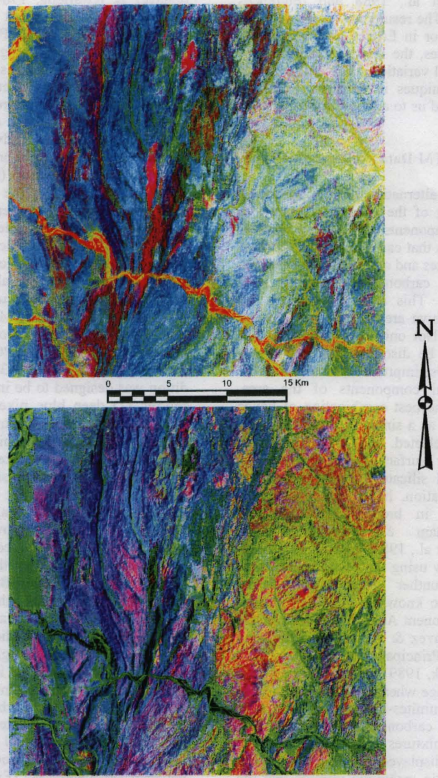

Figures 4 and 5 - (4) False Colour Composite of bands ratios TM5/TM7 (red), TM5/TMI (green) and TM5/TM4 x TM3/TM4 (blue) (ratios and band combination from Sultan et al., 1986; 1987) and (5) False Colour Composite of bands ratios TM5/TM4 (red), TM3/TM1 (green) and TM7/TM5 (blue) (ratios and band combination from Drury \& Berhe, 1993). 
Abrams et al., 1988 and references therein). The results however, were curiously poor in Eritrea for mapping of serpentinites, the images exhibiting little spectral variation. The ambiguity of ratio techniques in serpentinite detection, forced us to adopt a different strategy.

\section{Landsat TM Data - Alternative Tech- niques}

Our alternative strategy for image processing of the image data had two basic components. First, we address techniques that can map distributions of serpentinites and other hydroxyl-bearing silicates, carbonates, goethite and hematite. This is a crucial step for poorly known areas such as the Hagar Terrane. Not only it provides specific targets to be discriminated but it also gives a first impression of the possible lithological components of the area. Second, the best combination of bands to present as a single false-colour composite is selected.

Four surface types, namely hydroxylated silicates, goethite, hematite and vegetation, have been confidently identified in broad TM band data (Buckingham \& Sommer, 1983; Abrams et al., 1984; Prost, 1980; Hunt, 1991). By using the pseudo-ratio technique (Gunther et al., 1980; Hunt, 1991), also known as Selective Principal Component Analysis (Chavez et al., 1984; Chavez \& Kwarteng, 1989) and Pairwise Principal Components (Lamb \& Pendock, 1989) its is possible to create an image where the concentration of (1) serpentinites-hydroxyl-bearing silicates and carbonates, (2) iron oxides, and (3) mixtures between (1) and (2) can be displayed in a FCC. The pseudo-ratio technique implies that the application of PCA to two spectral bands can be expected to portray an approximation to albedo as $\mathrm{PC} 1$ and the uncorrelated spectral differences as PC2
(Chavez \& Kwarteng, 1989). Inspection of the two associated eigenvector matrices shows the single PCs most affected by the two grouping of features in the data. The technique self-compensates for atmospheric offset and multiplicative effects and it is proved advantageous over the approach of Loughlin (1991). Among such advantages de Souza Filho \& Drury - in press (b) - remarked on the following: (i) the much easier interpretation of the eigenvector data, which requires elementary expertise in PC analysis and little knowledge of the spectral characteristics of the targets; (ii) the substantial increase in the signal to noise ratios for all of the resultant images; (iii) minimum computing time. Figure 6 is a "Mineral Mapping Rendition" (MMR) produced using the pseudo-ratio method ( $\mathrm{PCs}$ produced from TM bands 5-7 and 1-3). This rendition was designed to be interpreted as follow: (1) deep blue pixels represent surfaces where the concentration of hydroxyl-bearing silicates is high; (2) cyan and bluish patches represent zones where hydroxyl-bearing silicates and iron-rich minerals co-exist (the content of iron-rich mineral being relatively low); and, (3) orange to brownish pixels zones are highly iron-stained.

Figure 6 shows that the two large bodies of serpentinite in TB1 are clearly distinguished from all lithologies (including impure marbles and volcaniclastics) as dark blue bodies. In fact, none of the other lithological components of this domain show intensities as those attributed to serpentinites except a a ridge of crystalline marbles in TB1. By using the pseudo-ratio technique one can approximate the actual spectral differences verified in the modelled ratios between TM 5 and TM7 (Fig. 3), where serpentinites show the highest values. In TB2 the results are more superior still when compared with the ones based on ratios. There, sparse outcrops 
and blocks of pyroxene cumulates verified in the field, are mapped with light blue hues and display an intriguing continuity. They were, however, completely missed in the ratio images. The MMR also display a very distinct broad spectral signature for both TB1 and TB2 based on their content of iron-rich surfaces. The olistostromic ophiolitic mélange comprising TB1 display surfaces dominantly iron-stained, whereas the intermediate to acidic arc volcanics rocks of TB2 are represented by ironpoor surfaces.

The level of information provided by the MMRs is too specific to be solely used in lithological mapping. In this regard MMRs are inferior to ratio images. A more complete outcome requires images capable of displaying large and interpretable spectral variations together with features associated with topography. The most efficient way to assess this sort of synergism is by producing a standard FCC based on inter-band correlation analysis (Davis, 1973). For the area considered here, TM bands 7, 4 and 2 are the least correlated between all TM bands and proved to be the most informative. Figure 7 shows a gaussian stretched TM $7,4,2$ (RGB) FCC. The MMR and the 742 FCC complement each other, but cannot be used on their own for mapping the complex Eritrean terrains. For example, serpentinites and pyroxene cumulates are not readily mapped in the $\mathrm{FCC}$ but are clear entities in MMR. Inversely, the FCC have direct meaning in terms of the composition and the surfaces of certain rocks, such as metabasalts, gabbros, diorites, granodiorites, etc; these are irresolvable in the MMR.

By merging our available field work and spectral data with the spectral and topographic information contained in both MMR and TM 742 FCC images, the map pictured in Figure 2 was produced. Unfortunately, there are no geological maps available for Eritrea to be used for comparison. Nevertheless, the colour distinctions revealed by both the TMM 742 FCC and MMR, correlate with general bedrock lithology and are only occasionally controlled by exposure effects such as scree slopes.

\section{CONCLUSIONS AND WIDER IMPLICATIONS}

\section{Remote Sensing Implications}

A surprising outcome of our field work across one of the largest tracts previously infered as ultramafic rocks (Drury \& Berhe, 1993; Sultan et al., 1993) was the minimum presence of serpentinites. Previous work confuses Eritrean serpentinites, impure carbonates, chloritic volcaniclastics, gabbros and some metabasalts (red renditions in Sultan et al., 1993). Drury \& Berhe (1993) mistook mixed terrains of diorites, andesites, some metabasalts and gabbros for serpentinites (their orangemagenta units), whereas serpentinites, impure marbles and some chloritic volcaniclastic are rendered in varied bluegreens. The reason, we believe, is previous authors' "calibration" of image processing strategy in lithologically and spectrally different terrains from those then unvisited in the Hahar Terrane; a bimodal serpentinite-granitoid area in the Central Eastern Desert of Egypt (Sultan et al., 1986) and one dominated by evolved and primitive calc-alkaline volcanics and their volcaniclastic products in NE Eritrea (Drury \& Berhe, 1993).

In lithologically diverse terrains such as the Pan-African, affected by regionally varied climatic conditions, it may not be possible to isolate all rock types using a single image product based on broad-band data. The synergism between two coloured images such as the pseudo-ratio MMR and an appropriate FCC is recommended. 

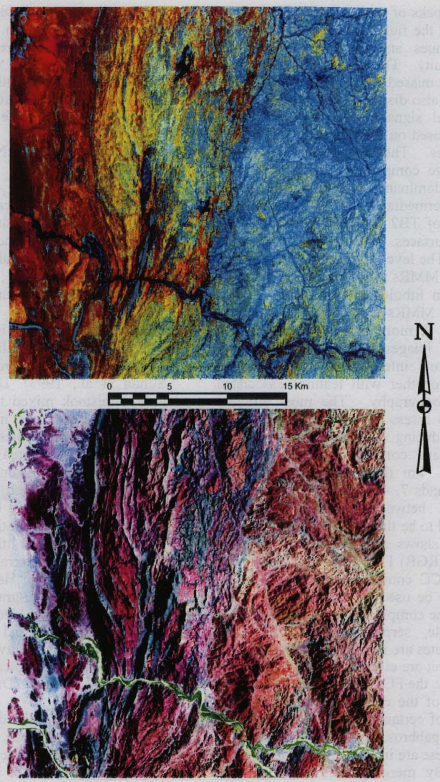

Figures 6 and 7 - (6) Landsat TM Mineral Mapping Rendition (MMR) produced using the pseudo-ratio technique and (7) Gaussian-stretched Landsat TM 7,4,2 (red, green, blue) false colour composite. 
Our results show that, although the pseudo-ratio method is scene-dependent, it invariably express the targetted features consistenly. The 3-band images are conformantly in the same hues, irrespective of date or season, except for variable effects of seasonal vegetation. In the Hagar Terrane, vegetation is scarce, even immediatly after the rainy season.

The use of the remote sensing strategy proposed here provide us with an excellent basis for geological mapping. Most of the features observed in the images correspond to genuine lithological variations on the ground. The serpentinite occurrences have been precisely mapped in the imagery. Our success is due to one important reason; weathering conditions in NW Eritrea ensure that iron in exposed rock and colluvium is expressed as hematite, goethite and other $\mathrm{Fe}^{3+}$ hydroxide species. In more arid areas, such as the Central Eastern Desert, serpentinites are spectrally quenched by exsolved magnetite with flat, low-albedo spectra (Sultan et al., 1986). This is one reason why impure carbonates are confused with serpentinites by quenching effect of carbonaceous material. Variation in residual magnetite across the NubianArabian Shield is also a function of depth of erosion below the early Tertiary palaesols responsible for the dominance of $\mathrm{Fe}^{3+}$ in Eritrea. We believe these factors resulted in the wrong lithological assortment obtained through the methods of Drury \& Berhe (1993) and Sultan et al. (1993) in Eritrea at least.

Using these simply enhanced TM data and relative little field control, we have demonstrated that the greenschist facies assemblages of NW Eritrea can be mapped with a high degree of confidence. Our first definitive mapping of small serpentinite bodies and the recognition of olistostromic mélanges carrying oceanic material close to the Barka lineament, suggest the existence of a "suture zone" in western Eritrea. This "suture zone" is bounded by the high grade gneissic rocks of the Barka Terrane to the west and a volcanic-plutonic, predominantly calc-alkaline association to the east (Fig. 8).

\section{Tectonic implications}

The evidence presented here for the presence of a major terrane accretionary boundary in western Eritrea resolves a lingering uncertainty about its existence, nature and location. It is demontrable that Northern Eritrea comprises a "telescoped" accretionary wedge - de Souza Filho and Drury - in press (a). Kroner et al. (1987) claimed that the previously unmapped terrains east of the Barka shear zone in Eritrea continue to the north in the hills south of Tokar (Sudan). There they described a dominant bimodal volcanic sequence composed of relatively minor amygdaloidal and pillowed basalts intercalated with voluminous units of rhyolite and ignimbrite and associated tuffs. Such a volcanic sequence is fundamentally different from the accretionary ophiolitic mélange and the primitive calc-alkaline suite described here (TB1 and TB2). In fact, our analysis of TM, OPS and Large Format Camera images together with the TM mosaic published by Sultan et al. (1993), reveals that the ophiolitic mélange unit is deflected westwards in the west flank of the Jebel Eisiemi (J.E.) syn-tectonic granite (Mohr, 1979), and 'dies out' in the Barka shear zone (Fig. 8). Similarly, the primitive calcalkaline suite becomes dramatically narrower northwards and terminates in a series of tight upright folds which are further north also intercepted by the J.E. granite. These units do not continue into the area to the north covered by the reconnaissance transverses of Kroner et al. (1991), and therefore were excluded from their analysis. 


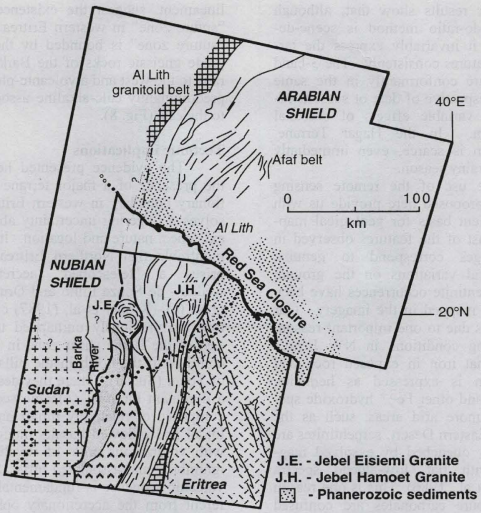

\begin{tabular}{|c|c|}
\hline BARKA TERRANE & HAGAR TERRANE \\
\hline+1 & Tectonic Block 1 \\
\hline $\begin{array}{l}\text { High Grade Gneissic } \\
\text { Complex }\end{array}$ & $\begin{array}{l}\text { accretionary wedge of ocean floor } \\
\text { (serpentinites = black) }\end{array}$ \\
\hline $\begin{array}{c}\text { ADOBHA A.TERRANE } \\
\text { 臣 }\end{array}$ & $\begin{array}{l}\text { Tectonic Block } 2 \\
\text { primitive volcanic arc crust }\end{array}$ \\
\hline Sedimentary Sequence & are silicic volcanics and volca \\
\hline $\begin{array}{l}\text { NACFA TERRANE } \\
\text { Volcanic Arc Sequence }\end{array}$ & $\begin{array}{l}\text { - evolved arc silicic volcanics and volcanoclastic } \\
\text { sediments } \\
\text { - deformed dioritic intrusion and volcanoclastic } \\
\text { sediments. }\end{array}$ \\
\hline
\end{tabular}

Figure 8 - Interpretation map draft over the published TM mosaic of Sultan et al. (1993) and complemented with information from TM and OPS enlargements and Large Format Camera images. 
of sheared and massive rhyolites with preserved flow-banding and ignimbritic textures in association with pyroclastics and volcanoclastics of similar composition, and extensive tracts of chloriteschists of undetermined provenance. In Eritrea, however, this sequence of highly evolved metavolcanics does not extend as far east as in Sudan but is bounded by a mature sedimentary sequence made up of clastic sediments and platform carbonates and devoid of volcanics (Adobha Abiy Terrane, Fig. 8). These are further east followed by another calc-alkaline association made of primitive submarine and more evolved arc volcanics (Nakfa Terrane). Detailed image analysis and field work around the Sudanese border show that the Adobha Abiy Terrane terminates south of the Jebel Hamoet (J.H.) syntectonic granite (Mohr, 1979) and does not continue further north. Similarly, the NNW-SSE trending strike of the Nakfa Terrane is cut by the same major shear zone as the Adobha Abiy Terrane, and do not proceed further north. This major boundary between eastern and western terranes is one of three or four that do not figure in any previous analysis of the southern Nubian shield.

The 'Afaf-Barka link' envisaged by Kroner et al. $(1987,1991)$ and Sultan et al. (1993) needs to be reviewed. Figure 8 shows that the Afaf belt may correlate with the eastern Hagar Terrane, but so far as we can judge the tangible evidence for a major suture zone does not cross the Red Sea (probably becomes cryptic) and the Barka, western Hagar, Adobha Abiy and Nacfa Terranes have no counterparts in Arabia. The whole range of new information provided here also demonstrates that the Tokar Terrane of Kroner et al. (1987, 1991) was defined on the basis of far and too broad features and perhaps their notion is of limited use. The same possibly applies to their Haya Terrane, in which high grade gneissic terrains such as those found in westernmost Eritrea (Barka Terrane - Fig. 8), were neglected from their analysis.

\section{ACKNOWLEDGEMENTS}

De Souza Fo, was funded by 'Coordenação de Aperfeiçoamento Pessoal de Nivel Superior - CAPES' during his $\mathrm{PhD}$ at The Open University - U.K.; where the basic ideas for this research emerged. De Souza Fo. also acknowledges the Conselho Nacional de Pesquisas (CNPq-Brazil) and Fundação de Amparo a Pesquisa no Estado de São Paulo (FAPESP) through research grants $301.227 / 94$ and 1996/11139-2, respectively (Universidade Estadual de Campinas), whose support made the accomplishment of this work possible. Field work was assisted by colleagues at the Mines and Water Resources Departments of Eritrea and sponsored by NERC (England). IRIS reflectance spectra of samples were measured using NERC-EPFS equipment (we are thankful to Liz Rolim for valuable advice).

\section{REFERENCES}

ABRAMS, M.J.; ROTHERY, D.A.; PONTUAL, A. (1988) Mapping in the Oman ophiolite using enhanced Landsat Thematic Mapper images. Tectonophysics, v.151, p.387-401. ABRAMS, M.J.; CONEL, J.E.; LANG, H.R. (1984) The joint NASA/ GEOSAT Test Case Project: final report. Tulsa, American Association Petroleum Geologists. 155p.

BERHE, S.M. (1990) Ophiolites in Northeastern and East Africa: implications for proterozoic crustal growth. Journal Geoleological Society. London, v.147, p. 41-57. BERHE, S.M.; ROTHERY,D.A. (1986) Interactive processing of satellite 
images for structural and lithological mapping in northeast Africa. Geological Magazine, v. 123, p. 393-403.

BEYTH, M. (1972) The geology of Central Western Tigre. Bonn, W. Germany, 326p. (Unpublished Ph.D. Thesis Rheinische FriedrichWilhelms Universitat).

BUCKINGHAM, W.F.; S.E. SOMMER (1983) Mineralogical characterization of rock surfaces formed by hydrothermal alteration and weathering: application to remote sensing. Economic Geology, v. 78, p. 664-674.

CHAVEZ JR, P.S.; KWARTENG, A.Y. (1989) Extracting spectral contrast in Landsat thematic mapper image data using selective principal component analysis. Photogrammetric Engineering \& Remote Sensing, v. 55 , n. 3, p. 339348.

CHAVEZ, P.S. JR.; GUPTILL, S.C.; BOWEL, J. (1984) Image processing techniques for thematic mapper data. In : ANNUAL ASPACSM SYMPOSIUM, 50., Washington, 1984. Proceedings. Washington, American Society of Photogrammetry. p.728-743.

DAVIS, J.C. (1973) Statistics and data analysis in geology. 2.ed. New York, John Wiley \& Sons. 328p.

DE SOUZA FILHO, C.R. (1995) Remote Sensing and the Tectonic Evolution of Northern Eritrea, Milton Keynes, England, 276p. (Unpublished $\mathrm{PhD}$ Thesis, The Open University, UK).

DE SOUZA FILHO, C.R.; DRURY, S.A. (in press - a), Preliminary Observations in a Pan-African Accretionary Wedge Terrane in North- western Eritrea, Journal of the Geological Society of London.

DE SOUZA FILHO, C.R.; DRURY, S.A. (in press - b) Evaluation of frequency filtered JERS-1 (Fuyo-1) and TM imagery for lithological mapping of gneissic terrains in arid environments. International Journal of Remote Sensing.

DRURY, S.A.; DE SOUZA FILHO, C.R. (submitted) Neoproterozoic terrane assembly in Eritrea: review and prospects. Journal of African Earth Sciences.

DRURY, S.A.; BERHE, S.M. (1993) Accretion tectonics in northern Eritrea revealed by remotely sensed imagery. Geological Magazine, v. 130, p. $177-190$.

FRANCAVIGLIA, A. (1938) Note sulla constituzione geologica del basso Barca (con carta geologica alla scala di 1:500.000). Giornale di Geologia. Bologna. Serie 2a, v. 8, p.129-138.

FRANCAVIGLIA, A. (1943) Osservazioni fatte nel bacino del basso Anseba (Eritrea). Bolletino dell Ufficio Geologico d' Itália, v. 67, n. 5, p. 1-13.

GUNTHER, F.J.; PODWYSOCKI, M.H.; BLODGET, H.W. (1980) Residual analysis of Landsat MSS images for rock discrimination. In : INTERNATIONAL GEOLOGICAL CONGRESS, 26., Paris, 1980. Abstracts. Paris, IUGS. v. 2, p. 71-74.

HUNT, G.A. (1991) Geological applications of reflected and emitted multispectral data over lateritised archean terrain in Western Australia. Milton Keynes, England, 290p. (Unpublished $\mathrm{PhD}$ Thesis, The Open University, UK). 
HUNT, G.R.; EVARTS, R.C. (1981) The use of near-infrared spectroscopy to determine the degree of serpentinization of ultramafic rocks. Geophysics, v. 46, p.316-321.

HUNT, G.R.; SALISBURY, J.W. (1970) Visible and near-infrared spectra of minerals and rocks: II. Carbonates. Modern Geology, v. 2, p. 23-30.

KAZMIN, V. (1976) Ophiolites in the Ethiopian Basement. Note. Ethiopia Institute Geological Survey, v. 53, p. 1-16.

KAZMIN, V. (1973) Geological map of Ethiopia (scale 1:2 million). Addis Ababa, Geological Survey.

KRONER, A.; LINNEBACJER, $\mathrm{P}$; STERN, R.J.; REISCHMANN, T.; MANTON, W.; HUSSEIN, I.M. (1991) Evolution of Pan-African island arc assemblages in the southern Red Sea Hills, Sudan, and in southwestern Arabia as exemplified by geochemistry and geochronology. Precambrian Research, v. 53, p. 99-118.

KRONER, A.; GREILING, R.; REISCHMANN, T.; HUSSEIN, I.M.; STERN, R.J.; DURR, S.; KRUGER, J.; ZIMMER, M. (1987) Pan-African crustal evolution in the Nubian segment of northeast Africa. In: KRÖNER, A.(ed.). Proterozoic lithosferic evolution. Washington, American Geophysical Union. p. 235-257. (Geodynamic Series, 17).

LAMB, A. D.; PENDOCK, N.E. (1989) Band Prediction Techniques for the Mapping of Hydrothermal Alteration. In : THEMATIC CONFERENCE ON REMOTE SENSING FOR EXPLORATION GEOLOGY, 7., Calgary, Alberta, Canada, 1989. Proceedings.
Michigan, Environmental Research Institute. p. 1317-1329.

LOUGHLIN, W.P. (1991) Principal component analysis for alteration mapping. Photogrammetric Engineering \& Remote Sensing, v. 57, n. 9 , p. 1163-1169

MILLER, M.M.; DIXON, T.H. (1992) Late Proterozoic evolution of the northern part of the Hamisama zone, northeast Sudan: constraints on PanAfrican accretionary tectonism. Journal Geological Society. London, v.149, p.743-750.

MILTON, E.J.; ROLIM, E.M. (1987) The geophysical environment research Inc. IRIS Mk_IV Spectroradiometer. UK. Users Notes. Southhampton, University of Southampton. 25 p. MOHR, P. (1979) Lithology and structure of the precambrian rocks of Eritrea. In: AL-SHANTI, A.M.S. (ed.). Evolution and mineralization of the Arabian-Nubian Shield. v. 2, p. 7-16.

PROST, G. (1980). Alteration mapping with airborne multispectral scanners. Economic Geology, v. 75, p. 894-906.

RIVARD, B. (1989) Mapping ophiolitic mélanges of the central Eastern Desert of Egypt using a linear mixing model applied to Landsat Thematic Mapper data. In: THEMATIC CONFERENCE ON REMOTE SENSING FOR EXPLORATION GEOLOGY, 7., Calgary, Alberta, Canada, 1989. Proceedings. Michigan, Environmental Research Institute. p. 243-253.

RIVARD, B.; ARVIDSON, R .E.; DUNCAN, I.J.; SULTAN, M.; EL KALIOUBY, B. (1992) Varnish, sediment, and rock controls on spec- 
tral reflectance of outcrops in arid regions. Geology, v.20, p. 295-298.

ROTHERY, D. (1987) Improved discrimination of rock units using landsat thematic mapper imagery of the oman ophiolite. Journal Geological Society. London, v.144, p. 587-597.

SHACKLETON, R. (1994) Review of Late Proterozoic sutures, ophiolitic mélanges and tectonics of eastern Egypt and north-east Sudan. Geologische Rundschau, v. 83 , n. 3, p. $537-546$.

STERN, R.J. (1994) Precambrian basement around Wadi-Halfa, Sudan: a bew perpsctive on the evolution of the East Saharan Craton. Geologische Rundschau, v.83, n. 3, p. $564-577$

STOESER, D.B.; CAMP, V.E. (1985)

Pan-African microplate accretion of the Arabian Shield. Geological Society of American Bulletin, v. 96, p.817-826.

SULTAN, M. BECKER, R.; ARVIDSON, R.E.; SHORE, P.; STERN, R,J.; EL ALFY, Z.; ATTIA, R.I. (1993) New constraints on red sea rifting from correlations of Arabian and Nubian Neoproterozoic outcrops. Tectonics, v.12, n. 6 , p. 1303-1319.

SULTAN, M.; BECKER, R.; ARVIDSON, R.E.; SHORE, P.; STERN, R.; EL ALFY, Z.; GUINNESS, E.A. (1992) Nature of the Red Sea crust: a controversy revisited. Geology, v.20, p. 593-596.
SULTAN, M.; ARVIDSON, R.E.; DUNCAN, I.J;; STERN, R.J.; EL KALIOUBY, B. (1988). Extension of the Najd shear system from Saudi Arabia to the central Eastern Desert of Egypt based on integrated field and Landsat observations. Tectonics, v.7, n. 6, p. 1291-1306.

SULTAN, M.; ARVIDSON, R.E; STURCHIO, N.C.; GUINNESS, E.A. (1987) Lithological mapping in arid regions with Landsat thematic mapper data: Meatiq dome, Egypt. Geological Society American Bulletin, v. 99, p.748-762.

SULTAN, M.; ARVIDSON, R. E; STURCHIO, N.C. (1986) Mapping of serpentinites in the eastern desert of egypt by using Landsat thematic mapper data. Geology, v.14, p. $995-$ 999.

USONI, L. (1952) Risorse mineralie dell'Africa Orientale: Eritrea, Etiopia, Somalia, Jandi Sapi. Roma, Ministero Dell'Africa Italiana, Ispettorato Generale Minerario. $553 \mathrm{p}$.

VAIL, J.R. (1987) Late Proterozoic tectonic terranes in the Arabian-Nubian Shield and their characteristic mineralization. Geological Journal, v. 22 , p. 161-174.

VAIL, J.R. (1985) Pan-African (late Precambrian) tectonic terrains and the reconstruction of the ArabianNubian shield. Geology, v.13, p. 839-842.

C.R.Souza Filho - Instituto de Geociências, Universidade Estadual de Campinas, Caixa Postal 6252, CEP 13081-970, Campinas, SP, Brasil. 